\begin{tabular}{|l|l|l||}
\hline \multicolumn{2}{|c|}{ PublisherInfo } \\
\hline \hline PublisherName & $:$ & BioMed Central \\
\hline \hline PublisherLocation & $:$ & London \\
\hline \hline PublisherImprintName & $:$ & BioMed Central \\
\hline \hline
\end{tabular}

\title{
Laying down the jaw
}

\begin{tabular}{|l|l|l||}
\hline \multicolumn{2}{|c|}{ ArticleInfo } \\
\hline \hline ArticleID & $:$ & 4562 \\
\hline \hline ArticleDOI & $:$ & $10.1186 /$ gb-spotlight-20020827-01 \\
\hline \hline ArticleCitationID & $:$ & spotlight-20020827-01 \\
\hline \hline ArticleSequenceNumber & $:$ & 228 \\
\hline \hline ArticleCategory & $:$ & Research news \\
\hline ArticleFirstPage & $:$ & 1 \\
\hline \hline ArticleLastPage & $:$ & 2 \\
\hline \hline & & RegistrationDate : 2002-8-27 \\
\hline ArticleHistory & $:$ & OnlineDate \\
\hline \hline ArticleCopyright & $:$ & BioMed Central Ltd2002-8-27 \\
\hline \hline ArticleGrants & $:$ & \\
\hline \hline ArticleContext & $:$ & 130593311 \\
\hline \hline
\end{tabular}




\section{Jonathan B Weitzman}

Email: jonathanweitzman@hotmail.com

The Dlx gene family has been linked to the evolution of the gnathostome (jawed vertebrate) skull. In the 22 August ScienceXpress, Depew et al. describe the affect of deleting Dlx5 and Dlx6 genes on the development of the mouse jaw (Sciencexpress, 22 August 2002, DOI:10.1126/science.1075703). They performed extensive in situ hybridization analysis of mutant embryos to study the expression of genes involved in branchial arch development. In the absence of Dlx5/6 they observed a 'homeotic' transformation of the lower jaw into an upper jaw. Depew et al. propose that the establishment of a pattern of nested expression of $D l x$ genes in the branchial arches contributed to the transition from jawless to jawed vertebrates.

\section{References}

1. Lamprey $D l x$ genes and early vertebrate evolution.

2. ScienceXpress, [http://www.sciencexpress.org]

3. The $D l x 5$ and $D l x 6$ homeobox genes are essential for craniofacial, axial, and appendicular skeletal development 